\title{
Pengembangan Kota Wisata Syariah dengan Peningkatan UMKM Syariah
}

\author{
Soraya Lestari \\ Novi Hardiyanti
}

Akuntansi, Universitas Ubudiyah Indonesia, Indonesia

Korespondensi penulis: soraya.lestari@uui.ac.id

\begin{abstract}
The growth of the Islamic economy is currently growing rapidly. This can be seen from the number of Micro, Small, and Medium Enterprises (MSMEs) that adopt the principles of Islamic business. Sharia MSME is a means of creating jobs and encouraging economic progresses, and advancing private sector businesses. The emergence of many new entrepreneurs who adopted the sharia system in Aceh becomes a great opportunity as a center for sharia products. Not only sharia products, Sharia MSMEs more broadly include the application of the Islamic financial system, including culture, entertainment, lifestyle, and tourism. The need for Aceh's flagship products wrapped in nuances of Islamic principles is still very limited in Aceh. It becomes an obstacle to make Aceh as a tourist destination with Islamic principles. The number of embroidery craftsmen is still less compared to the number of requests. This condition is based on the work that is still traditional and has not used a computerized machine yet. The limitations of human resource capabilities often become obstacles for using technology, production processes, and business development. The increase in sharia tourism will have a positive impact on the improvement of sharia MSMEs. This can be seen from the level of creativity, knowledge, and marketing according to tourist demand. The purpose of this study was to determine whether there is a significant influence of creativity, knowledge, and marketing to the improvement of Islamic MSMEs. This research has been conducted with questionnaires for the entrepreneurs' MSMEs of embroidery products in Aceh. The results of this study indicate that createvity, knowledge, and marketing simultaneously influence the improvement of sharia MSMEs. Partially, creativity and knowledge variables do not influence the improvement of sharia MSMEs, while marketing affects the improvement of sharia MSMEs significantly.
\end{abstract}

Keywords: Micro, Small, and Medium Enterprises (MSMEs); Sharia-based MSMEs; Sharia tourism; Creativity; Knowledge; Marketing.

Abstrak. Pertumbuhan ekonomi Islam saat ini berkembang pesat. Hal ini dapat dilihat
dari banyaknya Usaha Mikro, Kecil, dan Menengah (UMKM) yang mengadopsi prinsip
usaha syariah. UMKM syariah merupakan sebuah sarana menciptakan lapangan kerja
dan mendorong kemajuan perekonomian masyarakat, serta memajukan usaha sektor
swasta. Munculnya wirausaha-wirausaha baru yang mengadopsi sistem syariah di Aceh
menjadi peluang besar sebagai kiblat produk-produk syariah. Tidak hanya produk 
syariah, UMKM syariah secara lebih luas mencakup penerapan sistem keuangan Islam, termasuk budaya, hiburan, gaya hidup, dan pariwisata. Kebutuhan akan produk unggulan khas Aceh yang dibalut dalam nuansa Islami masih sangat terbatas di Aceh. Fakta ini menjadi kendala untuk menjadikan Aceh sebagai destinasi wisata berprinsip syariah. Jumlah pengrajin bordir di Aceh masih sangat kurang dibandingkan dengan jumlah permintaan produknya. Kondisi ini dilatarbelakangi penggerjaannya yang masih bersifat tradisional dan belum menerapkan sistem mekanisasi dan komputerisasi dalam proses produksinya. Terbatasnya kapabilitas sumber daya manusia sering menjadi penghambat dalam penerapan teknologi, pengembangan produksi, dan usaha. Peningkatan wisata syariah akan membawa dampak positif terhadap peningkatan UMKM syariah di Aceh. Hal ini dapat dilihat dari tingkat kreatifitas, pengetahuan, dan pemasaran produk yang dihasilkan sesuai permintaan wisatawan. Tujuan penelitian ini adalah untuk mengetahui apakah terdapat pengaruh kreatifitas, pengetahuan, dan pemasaran terhadap peningkatan UMKM syariah produk bordir di Aceh. Pengumpulan data dalam penelitian ini menggunakan kuesioner terhadap para pelaku UMKM syariah produk bordir di Aceh. Hasil penelitian ini menunjukkan bahwa kreatifitas, pengetahuan, dan pemasaran berpengaruh secara simultan terhadap peningkatan UMKM syariah produk bordir di Aceh. Secara parsial, variabel kreatifitas dan pengetahuan tidak mempunyai pengaruh secara signifikan, sedangkan variabel pemasaran berpengaruh signifikan terhadap peningkatan UMKM produk bordir syariah di Aceh.

Kata Kunci: UMKM syariah, Wisata syariah, Kreatifitas, Pengetahuan, Pemasaran.

Article Info:

Received: April 9, $2019 \quad$ Accepted: November 11, 2019 Available Online: November 15, 2019

DOI: http://dx.doi.org/10.30588/jmp.v9i1.437

\section{LATAR BELAKANG}

Usaha Mikro Kecil dan Menengah (UMKM) memiliki peran penting dalam kemajuan ekonomi negara (Undang-Undang Nomor 20 Tahun 2008). Hal ini dapat dilihat dari pentingnya penyelenggaraan UMKM yang berdampak luas terhadap pertumbuhan ekonomi, pemerataan, dan peningkatan pendapatan rakyat, menciptakan lapangan kerja yang luas, serta pengentasan kemiskinan. Pengembangan iklim usaha UMKM memberikan kesempatan serta dukungan kuat baik secara internal maupun eksternal bagi pelaku usaha. Perbedaan karakteristik UMKM dengan usaha besar membuat UMKM menjadi usaha yang banyak digeluti dan didominasi oleh masyarakat ekonomi lemah untuk meningkatkan perekonomian dan menurunkan tingkat pengangguran. UMKM memiliki prospek peningkatan yang baik dan memiliki peluang bisnis yang menjanjikan, karena proses restrukturisasi sektor korporasi dan BUMN (Badan Usaha Milik Negara) yang berlangsung lamban, sedangkan permintaan produk terus meningkat (Santoso \& Rahmawati, 2016).

Dari perspektif Islam, keberhasilan seorang pengusaha tidak hanya diukur dari segi keberhasilan materi. Hal ini karena kebutuhan manusia tidak hanya tunduk pada properti yang mereka miliki tetapi mencakup semua aspek yang dibutuhkan oleh masqasid al-shariah yaitu agama, kecerdasan, kehidupan, kehormatan, dan properti fisik (Yaacob \& Azmi, 2012). Menurut pandangan Islam, keberhasilan merupakan 
kemampuan seseorang untuk memberikan manfaat yang besar dan baik bagi orang lain. Keberadaan ekonomi mikro memberikan dampak positif terhadap perkembangan ekonomi, sehingga keuangan syariah memiliki peran penting dalam pembangunan ekonomi secara nasional. Dalam skenario pertumbuhan organik atau internal, perbankan syariah diperkirakan meraih pangsa pasar sebesar $20,7 \%$ pada tahun 2024. Namun, dalam skenario pertumbuhan yang dipercepat, pangsa pasar perbankan syariah dapat mencapai hingga 40,4\% pada tahun 2024 (BAPPENAS, 2015).

Hal ini menunjukkan bahwa ekonomi Islam akan berkembang semakin pesat di masa mendatang dan menjadi peluang besar bagi pelaku usaha khususnya UMKM, sehingga penting adanya upaya untuk menjadikan UMKM usaha berbasis syariah. Keberadaan UMKM syariah dianggap sangat penting untuk mendukung pergerakan ekonomi syariah dan destinasi wisata halal. Penelitian ini memberikan kontribusi pada peningkatan wisata syariah yang didukung dengan kesiapan UMKM berstandar syariah. Pengembangan ini perlu dilakukan, karena wisatawan muslim akan cenderung lebih memilih produk berstandar halal untuk digunakan.

Dalam regulasi, Aceh telah memiliki kekuatan hukum untuk mengembangkan pariwisata halal dan UMKM syariah yang didukung dengan penerapan Qanun nomor 10 tahun 2007. Regulasi tersebut mendukung penerapan ekonomi syariah dan UndangUndang nomor 33 tahun 2014 tentang jaminan produk halal di Indonesia, sehingga Aceh memiliki peluang besar untuk menjadi destinasi wisata syariah. Namun, kurangnya pengetahuan masyarakat masih menjadi kendala dalam pengembangan usaha syariah di Aceh dan penerapan wisata syariah secara menyeluruh. Hal ini sejalan dengan hasil penelitian Permadi, Darwini, Retnowati, Negara, \& Septiani (2018) yang menyebutkan bahwa penerapan wisata halal di Nusa Tenggara Barat mendapatkan sikap positif masyarakat dan didukung aturan hukum, peraturan daerah, dan sosialisasi tentang wisata halal. Di sisi lain, faktor internal dan eksternal sangat mempengaruhi eksistensi dan pertumbuhan UMKM. Kondisi ini dapat dilihat dari fluktuasi jumlah perusahaan mikro dan kecil menurut 2-digit Klasifikasi Baku Lapangan Usaha Indonesia (KBLI) (Tabel 1).

Tabel 1. Jumlah Perusahaan Mikro dan Kecil Menurut 2-digit KBLI*

\begin{tabular}{ccr}
\hline Tahun & Mikro & Kecil \\
\hline 2010 & 244.810 & 31.738 \\
2011 & 202.809 & 101.629 \\
2012 & 347.887 & 107.141 \\
2013 & 240.833 & 99.169 \\
2014 & 304.418 & 50.165 \\
2015 & 360.622 & 46.601 \\
\hline
\end{tabular}

Sumber: BPS (2018).

Keterangan:

*Jumlah perusahaan mikro dan kecil menurut 2-digit KBLI merupakan perusahaan yang mempunyai tenaga kerja berkisar antara 1-19 orang. Klasifikasi industri menggunakan survei bertaraf internasional, yaitu International Standard Industrial Classification of all Economic Activities (ISIC) yang telah disesuaikan dengan kondisi Indonesia dengan nama Klasifikasi Baku Lapangan Usaha Indonesia (KBLI).

Tabel 1 menunjukkan jumlah usaha mikro telah meningkat secara signifikan dari tahun ke tahun, sedangkan untuk usaha kecil masih mengalami fluktuasi dalam periode 
yang sama. Hal ini menunjukkan masih adanya ketidakmampuan pengusaha kecil dalam mengelola risiko usaha. Pada industri pakaian, pelaku usaha dituntut selalu mengikuti trend dan strategic goal yang tepat dan selalu update. Penelitian ini fokus pada UMKM produk bordir yang banyak digeluti oleh pengusaha rumah tangga di Aceh. Industri ini banyak diminati oleh pengusaha dengan latar belakang pendidikan terbatas. Mereka terbiasa menggunakan mesin bordir tradisional untuk berproduksi. Namun, seiring peningkatan UMKM bordir, pengusaha rumah tangga diharapkan dapat menggunakan teknologi bordir yang berbasis komputer untuk meningkatkan kapasitas produksi rumah tangga mereka. Mereka juga diharapkan untuk menerapkan usaha dengan prinsip-prinsip syariah dalam tata kelolanya.

Kendala pengetahuan menjadi salah satu kelemahan dalam peningkatan usaha UMKM syariah di Aceh. Kreatifitas dan pengetahuan juga menjadi hal penting dalam upaya tersebut. Kreatifitas akan menciptakan banyak inovasi yang unik dan terbaru, sedangkan pengetahuan akan menjangkau metode baru dalam pengembangan UMKM syariah. UMKM syariah di Aceh akan lebih termotivasi dengan meningkatnya kegiatan sektor pariwisata. Aceh memiliki warisan budaya yang khas dan kawasan alam yang indah. Sabang merupakan salah satu kabupaten di Provinsi Aceh yang menjadi destinasi wisata utama di Aceh. Sabang menjadi destinasi unggulan tingkat internasional di Aceh, karena Sabang menawarkan keindahan pantai dengan blue hole yang merupakan salah satu pantai terdalam di dunia yang didukung pelabuhan dengan lokasi strategis dan berpotensi menjadi destinasi berstandar halal internasional (BPPN, 2018). Di sisi lain, wisatawan akan lebih bergairah dengan banyaknya UMKM syariah yang memproduksi produk khas daerah dan produk unggulan daerah.

UMKM syariah diharapkan mampu menangkap peluang bisnis yang ada di tengah situasi ekonomi yang sulit. Oleh karena itu, UMKM syariah dituntut memiliki fleksibilitas tinggi dan didukung manajemen andal untuk menghasilkan produk dan jasa (Hejazziey, 2009). Perkembangan ekonomi syariah menjadi daya tarik tersendiri, baik di kalangan muslim maupun non-muslim, sehingga perkembangan tersebut menjadi alternatif dalam aktifitas perkonomian mereka (Santoso \& Rahmawati, 2016). UMKM syariah memiliki peluang besar untuk mendukung wisata syariah di Aceh. Namun, peningkatan UMKM syariah di Aceh untuk produk wisata belum mampu meningkatkan wisata syariah di Aceh, sehingga tingkat pengetahuan, kreatifitas, dan pemasaran menjadi faktor eksternal untuk mengukur pengembangannya. Berdasarkan uraian tersebut, tujuan penelitian ini adalah untuk mengetahui apakah ada pengaruh kreatifitas, pengetahuan, dan pemasaran terhadap peningkatan UMKM syariah produk bordir di Aceh.

\section{KAJIAN TEORITIS}

\section{Usaha Mikro, Kecil, dan Menengah (UMKM)}

Usaha mikro adalah usaha produktif milik perseorangan atau badan usaha yang memenuhi kriteria tertentu sebagaimana diatur dalam undang-undang (UU), sedangkan usaha kecil adalah usaha ekonomi produktif yang berdiri sendiri dan dijalankan oleh perorangan atau badan usaha yang bukan merupakan anak perusahaan atau bukan cabang perusahaan yang dimiliki, dikuasai, atau menjadi bagian langsung atau tidak langsung dari usaha menengah atau usaha besar yang memiliki kriteria usaha kecil yang diatur dalam undang-undang. Usaha menengah merupakan usaha produktif yang berdiri 
sendiri dan dilakukan oleh perorangan atau badan usaha yang bukan merupakan anak perusahaan atau cabang perusahaan yang dimiliki, dikuasai, atau menjadi bagian, baik secara langsung maupun tidak langsung dengan usaha kecil atau usaha besar dengan jumlah kekayaan bersih atau hasil penjualan tahunan sebagaimana diatur dalam (Sekretariat Negara, 2008). Dalam perspektif usaha, UMKM dikategorikan ke dalam empat kelompok, yaitu (Lembaga Pengembangan Perbankan Indonesia, 2015):

1. Sektor informal, yaitu sektor usaha dalam bentuk aktivitas ekonomi masyarakat seperti pedagang kaki lima.

2. Usaha mikro, yaitu usaha yang menggunakan kemampuan atau skill tertentu, tetapi kurang memiliki jiwa kewirausahaan untuk mengembangkan usahanya.

3. Usaha kecil dinamis, yaitu kelompok wirausaha yang melakukan usaha melalui jalinan kerjasama seperti ekspor.

4. Fast Moving Enterprise, yaitu wirausaha yang cakap dan siap bertransformasi menjadi usaha besar.

Tambunan (2012:10) menyatakan bahwa definisi dan konsep UMKM berbeda menurut setiap negara. Oleh karena itu, sulit untuk membandingkan seberapa penting peran UMKM antarnegara. Meskipun tidak ada kesepakatan umum untuk membedakannya, kriteria UMKM di Indonesia didasarkan UU Nomor 20 Tahun 2008 (Tabel 2).

Tabel 2. Kriteria UMKM di Indonesia

\begin{tabular}{clcc}
\hline \multirow{2}{*}{ No } & \multirow{2}{*}{ Jenis Usaha } & \multicolumn{2}{c}{ Kriteria } \\
\cline { 3 - 4 } & & Aktiva (Rp) & Omzet (Rp) \\
\hline 1. & Usaha Mikro & Maks. 50 Juta & Maks. 300 Juta \\
\hline 2. & Usaha Kecil & $>$ 50 Juta-500 Juta & $>$ 300 Juta-2,5 Miliar \\
\hline 3. & Usaha Menengah & $>$ 500 Juta-10 Miliar & $>2,5$ Miliar-50 Miliar \\
\hline
\end{tabular}

Sumber: Sekretariat Negara (2008).

Karakteristik merupakan bagian melekat pada setiap usaha yang dilakukan oleh UMKM sebagai ciri khas usaha tersebut. Tambunan (2012:166) menyatakan bahwa karakteristik yang melekat pada UMKM merupakan kelebihan dan kekurangan UMKM itu sendiri. Beberapa kelebihan yang dimiliki UMKM antara lain:

a. Daya Tahan

Pelaku UMKM dituntut mampu mempertahankan kelangsungan usahanya, karena mereka sangat adaptif menghadapi perubahan dalam lingkungan usaha, sehingga membutuhkan motivasi yang kuat.

b. Padat Karya

Umumnya, UMKM di Indonesia merupakan usaha padat karya. Proses produksi lebih mengandalkan kemampuan tenaga kerja yang dimiliki daripada mesin sebagai alat produksi.

c. Keahlian Khusus

Banyak UMKM di Indonesia yang masih membuat produk sederhana dengan keahlian khusus tanpa pendidikan formal. Keahlian tersebut diperoleh secara turuntemurun, sehingga produk yang dihasilkan memiliki nilai teknologi yang lebih sederhana dan murah. 


\section{d. Jenis Produk}

Produk yang dihasilkan UMKM umumnya bernuansa budaya yang diperoleh dari keahlian khas masyarakat di masing-masing daerah.

e. Permodalan

Pada umumnya, pelaku UMKM masih menggunakan modal sendiri dalam memulai usaha tanpa pendanaan dari sumber-sumber eksternal.

Kendala yang dihadapi UMKM seringkali menjadi kelemahan dalam menjalankan pengembangan usaha. Umumnya, UMKM sering menghadapi keterbatasan permodalan, kesulitan memasarkan produk, dan keterbatasan penyediaan bahan baku. Di samping kualitas sumber daya manusia (SDM) yang masih rendah dan manajemen keuangan yang tidak andal, pengetahuan yang dimiliki pelaku UMKM masih terbatas tentang dunia usaha dan penerapan teknologi. Seringkali, UMKM tidak mampu memfokuskan pembagian tugas yang jelas, sehingga pada praktiknya anggota keluarga sering diandalkan menjadi pekerja yang tidak dibayar (Tambunan, 2012:169).

Pesatnya pertumbuhan UMKM juga terjadi di Aceh. Aceh memiliki karakteristik syariah, sehingga Aceh mampu memunculkan UMKM syariah dengan spesifikasi tersendiri sesuai dengan syariah Islam, baik dari segi jenis usaha, sumber permodalan, sistem pengolahan, dan pemasaran. Berdasarkan data yang diperoleh dari Dinas Koperasi dan Usaha Kecil dan Menengah Provinsi Aceh (2017), kondisi UMKM Aceh mengalami pertumbuhan dari waktu ke waktu. Unit usaha dengan klaster menengah mencapai 1.733 unit dengan pertumbuhan sebesar $2 \%$ per tahun, unit usaha dengan klaster kecil sebanyak 20.258 unit dengan pertumbuhan sebesar $27 \%$ per tahun, serta unit usaha dengan klaster mikro berjumlah 53.216 unit dengan tingkat pertumbuhan $71 \%$ per tahun. Data UMKM tersebut mencakup berbagai macam industri. Namun, industri bordir pakaian merupakan satu usaha yang memiliki nilai kekhasan di Aceh dan banyak dilakukan secara turun temurun.

Industri bordir pakaian banyak dilakukan oleh ibu-ibu rumah tangga (home-based industry). Walaupun terbilang usaha kecil, tetapi usaha bordir pakaian dapat menyerap banyak tenaga kerja dan memiliki kapasitas produksi yang menjanjikan. Namun, jumlah pengusaha bordir di Aceh masih cukup rendah. Gambar 1 menunjukkan bahwa rata-rata jumlah pengusaha bordir di Aceh masih berada di bawah angka 100 orang. Artinya, jumlah pengusaha UMKM produk bordir di Aceh masih relatif sedikit. Konsumen Aceh masih banyak menggunakan produk bordir yang dihasilkan dari daerah lain. Kondisi ini mengindikasikan bahwa jumlah lapangan pekerjaan masih sedikit dan rendahnya hasil usaha maupun produk olahan daerah, sehingga upaya peningkatan jumlah pengusaha di daerah masih sangat dibutuhkan.

Dalam perkembangannya, banyak hambatan yang sulit diatasi oleh pelaku UMKM untuk beroperasi secara berkelanjutan terutama pengusaka mikro dan kecil. Hambatan utama dalam pertumbuhan industri syariah (Komite Nasional Keuangan Syariah, 2017) antara lain: (1) lemahnya visi dan koordinasi antara berbagai pemangku kepentingan; (2) kurangnya dukungan pemerintah untuk industri; (3) kurangnya kesadaran di antara masyarakat umum dan sektor bisnis; (4) masih rendahnya kualitas dan kuantitas sumber daya manusia; (5) konsentrasi berlebih pada pasar ritel; (6) terbatasnya modal di seluruh bank umum syariah dan bank perkreditan rakyat syariah; (7) isu kapasitas di dalam institusi keuangan syariah dalam variasi produk, persaingan harga, sistem dan teknologi informasi, serta tingkat pelayanan dan distribusi; (8) terbatasnya 
likuiditas dalam pasar modal syariah; (9) terbatasnya sumber pendanaan di sektor pasar modal syariah, perbankan, dan non-bank; (10) lemahnya pengawasan dalam keuangan mikro; dan (11) kurangnya transparansi dan tata kelola yang baik dalam sektor pendanaan syariah, termasuk dana haji, zakat, dan wakaf.

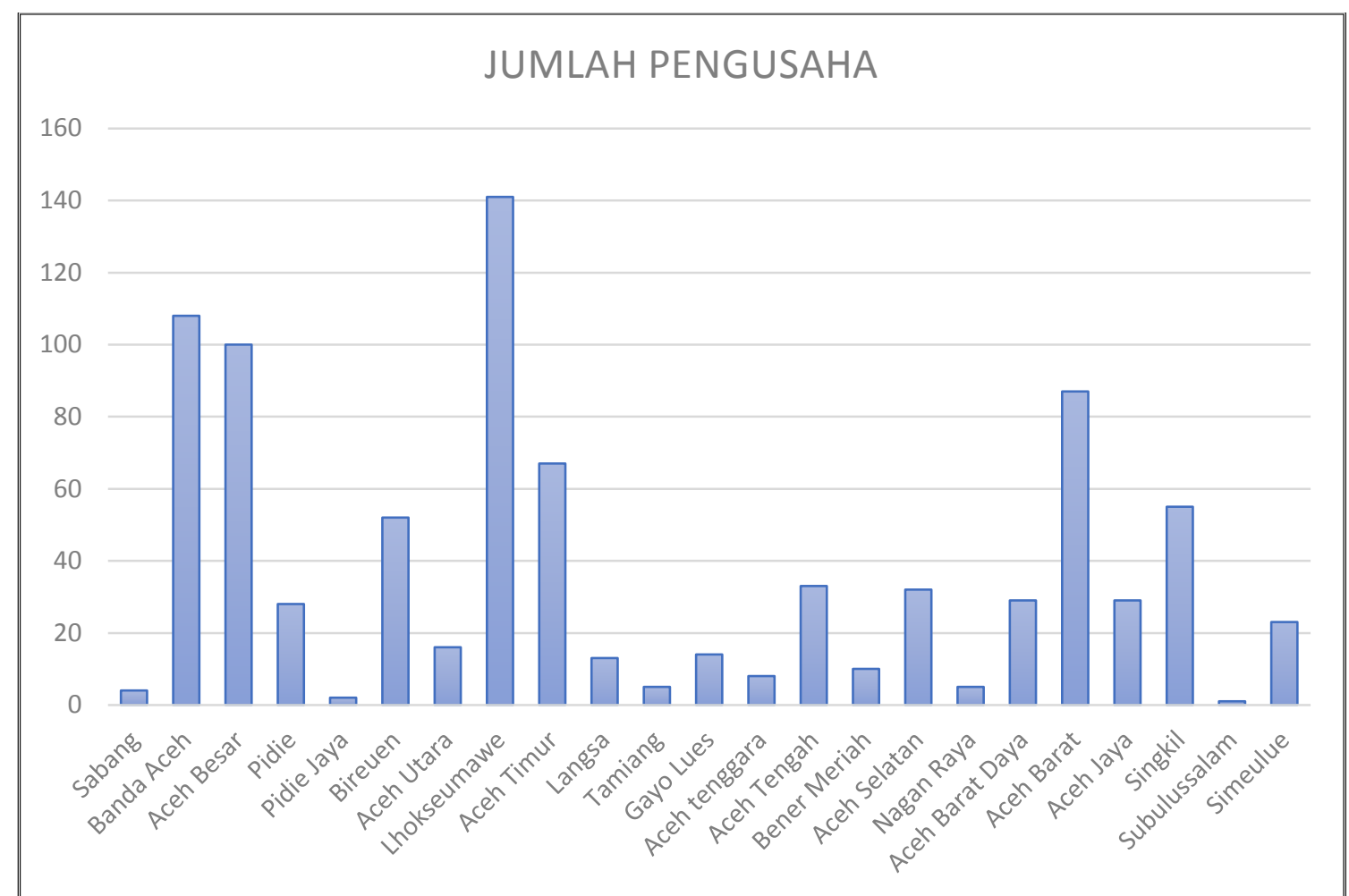

Sumber: Dinas Perindustrian dan Perdagangan Provinsi Aceh (2018).

\section{Gambar 1. Perkembangan UMKM di Aceh}

\section{UMKM Syariah dan Akses Pembiayaan}

UMKM syariah merupakan usaha mikro, kecil, dan menengah yang menggunakan proses pengolahan, pengelolaan, dan pendanaan berdasarkan prinsip-prinsip syariah. Sholihin (2010:51) menyatakan bahwa lembaga keuangan syariah merupakan lembaga keuangan yang operasinya dapat mengeluarkan produk keuangan syariah dan mendapatkan izin sebagai lembaga keuangan syariah, sedangkan produk keuangan syariah adalah produk keuangan yang mengikuti syariah Islam.

Perkembangan UMKM syariah memiliki potensi yang besar. Hal ini disebabkan adanya keselarasan antara tujuan pemerintah dalam melaksanakan syariat Islam di Kota Banda Aceh dan perilaku masyarakat Aceh yang mudah menyesuaikan diri dengan syariat Islam. Pengembangan UMKM difokuskan pada upaya memaksimalkan potensi diri. Namun, saat ini masih banyak UMKM yang tidak menerapkan aturan secara kondusif. Misalnya, masih banyak pungutan dan biaya yang diterapkan, sehingga kondisi itu mengakibatkan terjadi biaya tinggi dan pengurusan izin yang memakan waktu lama. Kondisi tersebut dikarenakan adanya biaya pengurusan izin yang tidak sedikit, sedangkan pemasukan dari usaha belum ada (Hejazziey, 2009). 
Dari sisi perbankan syariah, pengembangan UMKM merupakan pembiayaan yang memiliki porsi lebih besar daripada pembiayaan non-UMKM (Wibisono, 2015). Namun, akses pembiayaan yang lemah menjadi hambatan utama bagi pertumbuhan dan pengembangan UMKM. Hal ini disebabkan lembaga keuangan formal belum memiliki kepercayaan terhadap pendanaan operasi UMKM. Masalah ini disebabkan oleh faktor produksi yang berisiko dan tidak stabil akibat gagal bayar dan masalah dalam pelunasan kredit usaha. Lembaga keuangan formal dan komersial lebih cenderung memberikan pendanaan kepada perusahaan besar dan risiko usaha yang rendah. Ini terjadi karena adanya pengendalian terhadap tingkat bunga dan pemberian pinjaman oleh perantara keuangan kepada negara-negara sedang berkembang. Lembaga keuangan formal yang menyalurkan kredit kepada pengusaha kecil akan mandapatkan insentif yang kecil pula, karena biaya administrasi dan prosedur yang dikeluarkan tidak sebanding dengan kredit yang diberikan (Arsyad, 2008:14).

Pembiayaan kegiatan UMKM masih sering menjadi polemik antara lembaga keuangan dan pelaku usaha. Hal ini disebabkan keterbatasan sumber daya manusia untuk memperoleh akses pembiayaan. Akses untuk memperoleh pendanaan semakin berisiko dengan kenyataan bahwa usaka mikro dikelola oleh pengusaha yang hanya mendapatkan pendidikan dasar selama beberapa tahun saja. Persepsi yang muncul adalah pengusaha dengan tingkat pendidikan rendah tidak memiliki keberanian untuk meminta bantuan keuangan kepada lembaga pemberi pinjaman. Apabila faktor rendahnya tingkat pendidikan menjadi salah satu kendala terhadap akses pembiayaan UMKM, maka akses pembiayaan UMKM berpendapatan rendah perlu ditingkatkan (Arsyad, 2008:15).

\section{Peran UMKM dalam Perkembangan Ekonomi Daerah}

UMKM, baik secara langsung maupun tidak langsung, akan berpengaruh terhadap pertumbuhan ekonomi dan peningkatan kesejahteraan masyarakat daerah maupun nasional. Fakta menunjukkan bahwa hanya sektor UMKM yang mampu bertahan ketika terjadi krisis ekonomi tahun 1998 (Suci, 2017). Fakta ini menjadi motivasi bagi pemerintah untuk menumbuhkan minat masyarakat dalam berwirausaha. Keuntungan lain adalah dukungan terhadap pertumbuhan ekonomi dari sisi pengembangan inovasi dan teknologi. Pengembangan inovasi merupakan salah satu upaya pemerintah pusat, pemerintah daerah, pengusaha, dan masyarakat untuk meningkatkan dan memberdayakan pengusaha mikro, kecil, dan menengah dengan memberikan fasilitas bimbingan dan pendampingan untuk memperkuat, menumbuhkan, dan meningkatkan kemampuan dan daya saing UMKM (Nitisusastro, 2010:270).

Saat ini, perkembangan ekonomi daerah merupakan sebuah keharusan, karena dukungan finansial oleh pemerintah dalam bentuk anggaran desa. Setiap desa dapat mengambil bagian dalam peningkatan pertumbuhan ekonomi melalui penciptaan produk khas daerah yang berdaya saing. Banyaknya produk yang diciptakan oleh suatu daerah dapat meningkatan ekonomi daerah tersebut. Setiap daerah juga diharapkan mampu untuk menjalin kerjasama luar negeri dalam rangka memperkenalkan produk khas daerah yang berbasis budaya.

Berwirausaha dan menciptakan produk khas daerah dapat meningkatkan kemandirian seseorang. Semakin banyak warga negara yang mampu menciptakan produk melalui kegiatan berwirausaha akan meningkatkan kemandirian masyarakat, sehingga mereka akan lebih produktif. Sebaliknya, masyarakat yang tidak produktif akan berisiko 
terhadap tingginya pengangguran (Nasution, Setyanto, Huda, Mufraeni, \& Utama, 2012: 116). Namun, banyak pula kendala yang dihadapi dalam berwirausaha, antara lain: (a) akses yang rendah terhadap sumber-sumber informasi; (b) rendahnya kemampuan untuk meningkatkan akses dan peluang pasar; (c) kemampuan dan akses terhadap sumber pendanaan dan perbankan yang rendah; (d) kemampuan penguasaan teknologi yang masih terbatas; (e) rendahnya kemampuan mengembangkan organisasi dan manajemen; dan (f) lemahnya pembentukan jaringan usaha atau kemitraan antara sesama usaha kecil dan besar (Hejazziey, 2009). Menjadi wirausaha bukanlah suatu kemampuan yang bersifat instan. Ada pun beberapa bakat yang lazim dimiliki oleh wirausaha (Nitisusastro, 2010:29) antara lain: kemauan dan rasa percaya diri, berani mengambil risiko, pekerja keras, fokus pada sasaran, berani mengambil tanggung jawab, dan inovatif. Untuk mencapai kesuksesan berwirausaha, seseorang dapat mengasah diri melalui kegiatan pelatihan dan bimbingan teknis mengelola suatu usaha, sehingga usaha yang dijalankan dapat going concern.

\section{Pertumbuhan Produk Syariah di Aceh}

Kemajuan budaya Islam memberikan kontribusi sangat besar terhadap pertumbuhan ekonomi syariah saat ini. Tidak hanya perbankan syariah, permintaan pasar mendorong pertumbuhan ekonomi syariah dan sistem pemerintahan syariah. Semenjak dimulainya syariat Islam, Aceh telah menghasilkan banyak Qanun yang mengatur tata kelola pemerintahan di Aceh dalam bingkai syariah. Demikian pula dengan pertumbuhan produk syariah di Aceh yang diatur dalam Qanun Nomor 8 Tahun 2016 tentang Sistem Jaminan Produk Halal. Produk halal merupakan barang/produk dari hasil proses produksi yang telah dinyatakan halal sesuai tuntunan syariah Islam. Proses menciptakan produk halal adalah melakukan serangkaian kegiatan untuk menjamin kehalalan produk, yakni penyediaan bahan, pengolahan, penyimpanan, pengemasan, pendistribusian, penjualan, dan penyajian produk (Sekretaris Daerah Aceh, 2016).

Dalam pasal 45 Qanun Nomor 8 Tahun 2016, pertumbuhan produk halal di Aceh juga didukung oleh kebijakan pemerintah dengan memberikan pendanaan dalam memperoleh sertifikasi halal kepada UMKM dan seluruh perusahaan yang beroperasi di Aceh diwajibkan memberikan pendanaan kepada UMKM sebagai bentuk pertanggungjawaban sosial perusahaan (corporate social responsibility). Kebijakan ini dapat menjadi peluang besar untuk menumbuhkan banyak UMKM syariah di Aceh. Pelaku UMKM seharusnya dapat melihat peluang pasar tersebut. Sukamto (2012) menyatakan bahwa pasar merupakan sebuah mekanisme yang telah berlangsung lama, yaitu tempat terjadinya pertukaran produk berupa barang atau jasa yang terjadi secara alamiah. Nasution dkk. (2012:111) menjelaskan beberapa kaidah dalam berproduksi antara lain: (1) barang dan jasa yang diproduksi merupakan produk halal pada setiap tahapannya; (2) terhindar dari kerusakan lingkungan; (3) produksi dilaksanakan untuk kemaslahatan manusia dan mencapai kemakmuran masyarakat; (4) dalam hukum Islam, produksi berarti memandirikan umat; dan (5) meningkatkan kualitas SDM yang dilakukan secara spiritual, mental, maupun fisik. Produksi harus memperhatikan kemaslahatan, artinya produk yang diciptakan adalah produk yang memberikan kemanfaatan dan menciptakan kemaslahatan. Penciptaan produk yang bersertifikasi halal menjadi trend dalam menciptakan produk yang baik dan juga membangkitkan keyakinan konsumen bahwa produk yang dibeli layak untuk digunakan. 


\section{Pengembangan Kota Wisata Syariah dan Dampaknya terhadap Peningkatan UMKM}

Pengembangan kota syariah di Indonesia masih menjadi isu menarik terutama di Aceh. Wisata syariah merupakan sebuah potensi ekonomi yang sangat besar untuk dikembangkan mengingat mayoritas penduduk Aceh beragama Islam. Namun, wisata syariah tidak hanya berfokus pada banyaknya wisatawan muslim, tetapi juga tidak menutup akses untuk wisatawan non-muslim. Oleh karena itu, salah satu upaya mengembangkan pariwisata syariah adalah meningkatkan produk dan daerah tujuan wisata syariah (Kementerian Pariwisata, 2015). Peningkatan kualitas produk dapat menarik minat wisatawan, yaitu produk yang dihasilkan tersebut merupakan produk yang memiliki nilai budaya tinggi, seni, dan kearifan masyarakat lokal.

Konsep wisata syariah dapat memberikan jaminan keamanan dan kenyamanan serta public trust terhadap produk dan kualitasnya. Aceh diharapkan mampu menjadi destinasi kota wisata syariah pertama yang menyediakan produk-produk halal yang dapat menjadi brand dan contoh bagi kota-kota lain di Indonesia. Oleh karena itu, keseriusan pemerintah dibutuhkan untuk mengembangkan wisata syariah ini, sehingga langkah awal adalah mengubah konsep busana yang sebelumnya bercermin pada dunia barat menjadi konsep busana syariah yang sesuai dengan syariat Islam. Produktifitas tidak menuntut latar belakang profesi dalam praktiknya. Namun, masyarakat yang produktif dituntut untuk lebih kreatif menghasilkan produk dan jasa sesuai dengan bidang keahliannya (Nasution dkk., 2012:117). Oleh karena itu, Aceh harus mampu menciptakan brand produk syariah yang banyak dicari wisatawan.

Pengembangan wisata berbasis syariah mencakup beberapa prinsip antara lain: (1) pengembangan fasilitas untuk tujuan wisata berbasis syariah dapat dilakukan dengan skala besar maupun kecil, serta layanan intensif yang tidak jauh dari lokasi; (2) peningkatan UMKM dengan menitikberatkan fasilitas dan layanan berbasis syariah yang dilakukan oleh masyarakat lokal; dan (3) pengembangan wisata berbasis syariah didasarkan pada budaya dan alam setempat (Mardiah \& Herlinda, 2017). Kini, konsep halal telah menjadi gaya hidup masyarakat Aceh. Namun, kondisi tersebut harus diikuti dengan penyediaan fasilitas dan produk yang dihasilkan oleh masyarakat Aceh, sedangkan perilaku merupakan faktor yang mempengaruhi gaya hidup. Ada beberapa faktor yang mempengaruhi perilaku konsumen, di antaranya adalah lingkungan keluarga, kelompok sosial, tempat kerja, agama, situasi, norma yang berlaku, dan lain-lain (Mardiah \& Herlinda, 2017). Perilaku yang sesuai syariah akan mendukung pertumbuhan produk-produk syariah dan mendorong peningkatan pariwisata syariah di Aceh.

Hasil penelitian yang dilakukan oleh Battour, Ismail, dan Battor (2010) menunjukkan bahwa trend masa depan wisata halal tumbuh sebagai peluang bisnis di tahun yang akan datang. Tumbuhnya wisata halal sebagai bisnis diharapkan dapat merangsang individu dan organisasi pelaku usaha agar lebih sadar untuk terlibat dalam industri pariwisata dan perhotelan yang memberikan implikasi besar pada ketaatan syariat oleh umat Islam. Hasil penelitian yang dilakukan oleh Henderson (2010) menyatakan bahwa untuk menilai rencana asli dan strategis perusahaan baru perlu melibatkan faktor sosiokultural para pelancong yang harus beradaptasi dengan keadaan lokal. Kepatuhan syariah tidak dapat dipisahkan dari perkembangan dunia dan situasi yang menggambarkan cara bagaimana pariwisata dan perhotelan dihadapkan pada kekuatan eksternal guna menciptakan peluang bagi praktisi. Hasil penelitian yang dilakukan oleh Henderson 
(2009) menyatakan bahwa adanya kesempatan bagi pemasok muslim dan industri pariwisata internasional pada umumnya untuk menunjukkan kesadaran terhadap kualitas produk dan kebutuhan para pelaku pariwisata Islam untuk merangkul masyarakat di setiap lokasi di mana persyaratan agama harus dihargai. Berdasarkan penelitian sebelumnya tersebut, maka hipotesis 1 dirumuskan sebagai berikut:

\section{$\mathrm{H}_{1}$ : Terdapat pengaruh signifikan kreatifitas, pengetahuan, dan pemasaran seca- ra simultan terhadap peningkatan UMKM syariah.}

\section{Kreatifitas}

Kreatifitas merupakan keterbukaan terhadap pengalaman, melihat sesuatu dengan sudut pandang berbeda, menerima dan merekonsiliasi hal-hal yang bertentangan dengan toleransi terhadap sesuatiu yang tidak jelas, serta independen dalam mengambil keputusan untuk berpikir dan bertindak (Hadiyati, 2011). Kreatifitas tidak hanya dilakukan melalui penciptaan produk unggulan baru, tetapi juga dapat dilakukan dengan menjadi follower terhadap produk yang telah ada (Nitisusastro, 2010). Kreatifitas adalah perilaku inisiatif yang dilakukan terhadap suatu produk dengan memberikan nilai yang lebih bermanfaat, sehingga perilaku tersebut menjadi pedoman yang menuntun orang-orang untuk mampu mengerti, mempelajari, atau menemukan sesuatu yang baru (Hadiyati, 2011).

Pelaku usaha tanpa kreatifitas akan menghasilkan kejenuhan. Kreatifitas dalam UMKM dapat mendorong pelaku usaha lebih produktif menghasilkan produk. Menurut Zimmerer, Scarborough, \& Wilson (2008), perilaku yang dapat merangsang munculnya kreatifitas, antara lain kreatifitas sebagai nilai inti perusahaan, merangkul keberagaman, menumbuhkan nilai kreatifitas, berani mengambil risiko, keingintahuan yang tinggi, tidak monoton, melihat masalah sebagai tantangan, memberikan pelatihan kreatifitas, dukungan yang intensif, mengembangkan prosedur dan memberikan ide/masukan, ramah terhadap pelanggan, mencari tahu kegunaan produk terhadap kompetitor, memberikan penghargaan, dan memberikan contoh perilaku kreatif. Kreatifitas masyarakat dapat diasah melalui keikutsertaan pelatihan dan pemberdayaan. Masyarakat yang tinggal di daerah terpencil belum mampu mengasah kreatifitas karena kurangnya pengetahuan. Penyelenggaraan pelatihan oleh pemerintah desa akan memotivasi kemauan dan menumbuhkan keinginan untuk membangun desa yang lebih maju. Kondisi ini akan mendorong masyarakat desa berfikir kreatif dan produktif.

Hasil penelitian yang dilakukan oleh Hendrawan dkk, (2019) menyatakan bahwa terdapat pengaruh dimensi kreatifitas personal terhadap pengembangan UMKM, tidak terdapat pengaruh dimensi kreatifitas proses terhadap pengembangan UMKM, terdapat pengaruh dimensi kreatifitas produk terhadap pengembangan UMKM, dan terdapat pengaruh dimensi kreatifitas press/dorongan terhadap pengembangan UMKM. Penelitian yang dilakukan oleh Agyapong (2010) memperoleh tiga hasil penting. Pertama, pemerintah harus bekerjasama dengan pemilik dana untuk lebih perhatian kepada UMKM, karena banyaknya perhatian kepada UMKM berarti mengurangi kemiskinan dan meningkatkan standar hidup banyak warga Ghana. Kedua, UMKM harus berjejaring dan dapat membangun reksadana untuk dijalankan dan dikelola oleh pemilik UMKM. Ketiga, pemilik usaha kecil dan yang sudah ada perlu membentuk kemitraan dengan cara mengumpulkan bakat, ketrampilan, dan modal. Mengumpulkan bakat arti- 
nya mengasah kreatifitas yang dimiliki. Berdasarkan penelitian sebelumnya tersebut, maka hipotesis 2 dirumuskan sebagai berikut:

\section{$\mathrm{H}_{2}$ : Terdapat pengaruh signifikan kreatifitas terhadap peningkatan UMKM Sya- riah.}

\section{Pengetahuan}

Keterbatasan pengetahuan merupakan salah satu faktor penghambat wirausaha dalam menjalankan usahanya. Bagi pelaku usaha kecil, keterbatasan tidak hanya ditemukan dalam pendanaan dan peralatan fisik yang diperoleh, tetapi juga kemampuan akses terhadap informasi yang masih rendah (Nitisusastro, 2010:42). Bagi pengusaha rumah tangga, peningkatan pengetahuan dapat dilakukan dengan mengikuti beberapa pelatihan yang diselenggarakan di desa, memanfaatkan internet sebagai media pembelajaran, dan mengikuti seminar-seminar wirausaha yang banyak diselenggarakan oleh instansi dan perusahaan. Transformasi dari teknologi tradisional menjadi teknologi modern tidak mudah diterapkan tanpa pengetahuan yang memadai. Wirausaha yang memiliki cukup pengetahuan terhadap usaha yang dijalankan akan mampu meningkatkan profitabilitas usaha secara berkelanjutan. Aribawa (2016) menyebutkan salah satu cara yang dapat dilakukan oleh wirausaha untuk meningkatkan kinerja adalah memperkaya pengetahuan pelaku UMKM tentang pengelolaan keuangan, sehingga mereka mampu mengelola usaha secara profesional dengan akuntabilitas yang tinggi.

Dalam menjalankan usaha bordir, pelaku UMKM perlu memiliki pengetahuan tentang produk dan pengembangan usaha. Pengetahuan tentang produk yang baik dapat meningkatkan kreatifitas membuat produk baru dan berinovasi terhadap produk lama, sedangkan pengetahuan dalam pengembangan usaha dapat mengantarkan mereka melihat peluang usaha. Menurut Nitisusastro (2010:72), tujuan manajemen SDM antara lain fokus terhadap pencapaian tujuan, pengelolaan tenaga kerja yang ahli dan trampil, perencanaan dan penyelenggaraan pendidikan dan pelatihan, motivasi pegawai, peningkatan kepuasan kerja dan rasa percaya diri, sosialisasi setiap kebijakan manajemen, konsisten terhadap kebijakan tentang etika dan tanggung jawab sosial perusahaan, dan pembinaan hubungan dan kerjasama antarpegawai dan masyarakat.

Hubungan kerja dan kemitraan yang baik dibangun atas dasar pengetahuan, ketrampilan, dan kemampuan SDM. Jenjang karir harus transparan agar manajemen lebih bersifat terbuka terhadap kualitas dan prestasi pegawai (Ellitan, 2002). Dalam industri syariah, pengetahuan tentang Islam dan produk halal merupakan hal pokok dalam menjalankan proses produksi mereka. Sumber daya, bahan dasar, hingga pola pemasaran secara Islami telah dicontohkan dalam diri Nabi Muhammad SAW, sehingga wirausaha yang menerapkan prinsip syariah dengan benar akan lebih mudah untuk mengembangkan usahanya secara berkelanjutan. Hasil penelitian yang dilakukan oleh Rehman, Mahmood, Sugathan, \& Amin (2010) menyatakan bahwa pengembangan SDM sangat penting dengan rata-rata tertimbang 6,73. Angka tersebut menunjukkan bahwa pengembangan SDM dapat menciptakan kesadaran di antara para karyawan tentang pentingnya pelatihan dan pendidikan. Hal ini mencerminkan bahwa pengetahuan memiliki peran penting untuk peningkatan UMKM syariah. Penelitian yang dilakukan oleh Bharati dan Chaudhury (2006) memperoleh hasil bahwa perusahaan mikro dan kecil harus terhubung dengan jaringan profesional dan pribadi yang merupakan tugas badan sektor publik untuk menyediakan pengetahuan dan dukungan yang 
diperlukan. Misalnya, penawaran pengetahuan berbasis web dan laboratorium. Laboratorium juga memiliki dampak signifikan terhadap pengembangan pemahaman tentang teknologi. Berdasarkan penelitian sebelumnya tersebut, maka hipotesis 3 dapat dirumuskan sebagai berikut:

\section{$\mathrm{H}_{3}$ : Terdapat pengaruh signifikan pengetahuan terhadap peningkatan UMKM syariah.}

\section{Pemasaran}

Pemasaran produk berhubungan erat dengan penjualan. Dalam pemasaran, pelaku usaha harus mengetahui dengan pasti kebutuhan dan keinginan konsumen. Produk yang sesuai dengan keinginan konsumen akan lebih mudah terjual di pasar. Mengembangkan pemasaran mempunyai beberapa alternatif (Nitisusastro, 2010:99), yaitu membuat pasar baru bagi produk yang telah ada, membuat pasar baru bagi produk baru, mengembangkan pasar yang ada bagi produk baru, dan mengembangkan pasar yang ada bagi produk yang sudah ada.

Ferdinand (2000) dalam Hanfan (2017) menyatakan bahwa banyak strategi pemasaran yang digunakan dengan berbagai pendekatan yang dilakukan untuk fokus melakukan diferensiasi yang tidak dilakukan untuk menyamai pesaing, tetapi untuk memberikan nilai lebih. Sistem pemasaran yang tidak efektif dan efisien seringkali menjadi masalah utama bagi pemasaran produk UMKM. Menurut Hejazziey (2009), permasalahan tersebut antara lain bersumber pada: (1) masih lemahnya organisasi dan manajemen usaha; (2) lemahnya struktur permodalan dan keterbatasan mendapatkan akses sumber pendanaan; (3) lemahnya akses pasar dan penguasaan pangsa pasar; (4) keterbatasan memanfaatkan teknologi terutama teknologi terapan; (5) rendahnya kualitas SDM menyangkut kompetensi, ketrampilan, etos kerja, karakter, dan kesadaran pentingnya konsistensi kualitas dan standarisasi produk dan jasa, serta wawasan kewirausahaan; (6) lemahnya persediaan bahan baku, standarisasi kualitas produk, dan panjangnya rantai distribusi bahan baku; dan (7) kemitraan yang ada cenderung mengalami distorsi pada tingkat implementasi, sehingga lebih berdampak pada subordinasi pelaku usaha mikro, kecil, dan menengah daripada mitra usahanya.

Penelitian yang dilakukan oleh Asih \& Asih (2015) menyatakan bahwa untuk mengembangkan prospek pariwisata syariah, pemerintah harus menggunakan strategi pemasaran dalm bentuk marketing mix. Hasil penelitian tersebut menunjukkan strategi pemasaran dapat membuat wisata syariah sebagai market leader dalam sektor pariwisata di Indonesia. Hasil penelitian yang dilakukan oleh Kamali (2011) menyatakan bahwa ada dua aspek dalam pariwisata Islam; Pertama, yang berhubungan dengan ketaatan pada pedoman syariah; Kedua, untuk pengembangan pasar. Perusahaan dan operator pariwisata Islam secara kontinyu perlu meningkatkan dan mendiversifikasikan produk dan layanan mereka, serta memberikan paket yang lebih menarik untuk kebutuhan umat Islam di seluruh dunia. Hal ini menunjukkan bahwa pemasaran merupakan strategi penting dalam pengembangan UMKM syariah menuju wisata syariah. Berdasarkan penelitian sebelumnya tersebut, maka hipotesis 4 dapat dirumuskan sebagai berikut:

\section{$\mathrm{H}_{4}$ : Terdapat pengaruh signifikan pemasaran terhadap peningkatan UMKM syariah.}




\section{Kerangka Konseptual}

Penciptaan kota wisata syariah merupakan salah satu konsep pengembangan ekonomi syariah saat ini. Munculnya destinasi wisata syariah, maka daerah tersebut secara tidak langsung akan membuat banyak regulasi terkait dengan syariat Islam. Meningkatnya destinasi wisata syariah diharapkan dapat memperluas jangkauan pengembangan konsep ekonomi syariah, termasuk UMKM syariah. Pembaruan UMKM menjadi UMKM syariah perlu dilakukan. Banyak prinsip-prinsip yang berbeda antara UMKM dan UMKM syariah sebagai sarana meningkatkan wisata syariah melalui pengelolaan kreatifitas, pengetahuan, dan pemasaran. Secara umum, model penelitian ini dirumuskan dalam Gambar 1 berikut ini.

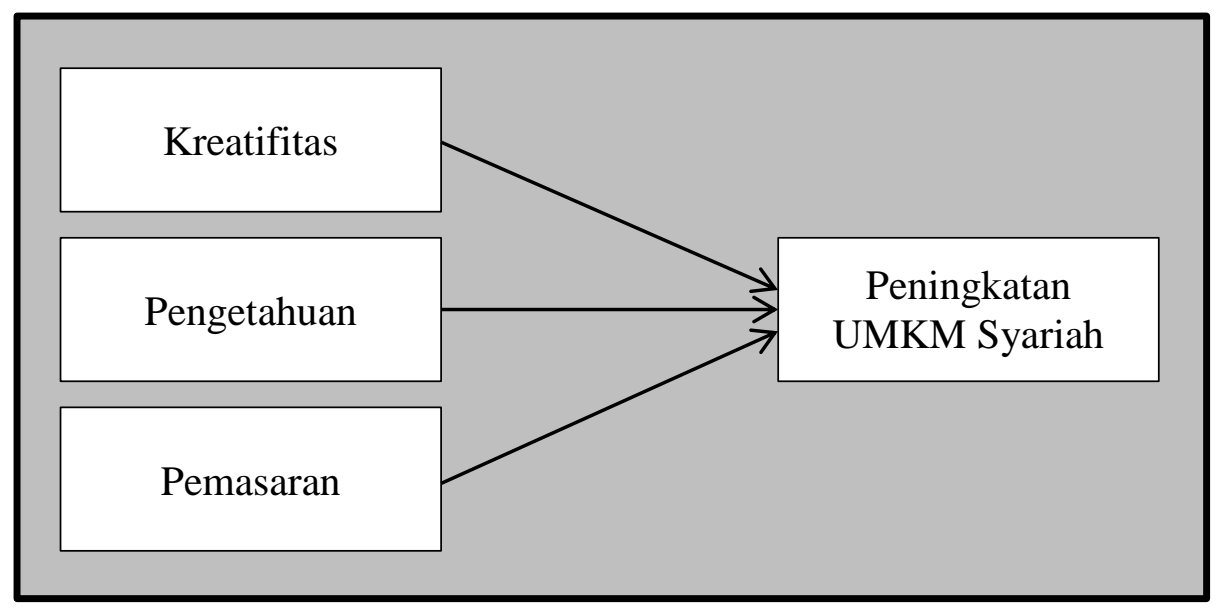

Gambar 1. Model Penelitian

Kreatifitas berpengaruh terhadap peningkatan UMKM syariah. Hal ini dikarenakan peningkatan kreatifitas akan berdampak terhadap peningkatan UMKM syariah. Kreatifitas yang tinggi akan meningkatkan produktifitas untuk menghasilkan barang/ jasa pada sekelompok masyarakat. Hal ini diharapkan berdampak positif terhadap pertumbuhan UMKM syariah. Pertumbuhan UMKM syariah akan menghasilkan banyak produk syariah lokal yang dapat menjadi daya tarik tersendiri bagi masyarakat lokal dan luar daerah. Produk yang dihasilkan oleh pelaku UMKM syariah diharapkan dapat bervariasi, sehingga metode tersebut membutuhkan inovasi baru yang muncul dari pengetahuan yang diperbaruhi. Pengetahuan masyarakat memiliki pengaruh signifikan terhadap peningkatan UMKM syariah, yaitu dengan pengetahuan, masyarakat diharapkan dapat memperoleh modal usaha, menciptakan produk yang bernilai guna, serta melakukan pemasaran yang tepat sasaran. Pada gilirannya, upaya tersebut dapat meningkatkan pertumbuhan UMKM syariah. Dengan pengetahuan yang memadai, pelaku usaha diharapkan mampu bertahan dalam persaingan pasar yang semakin ketat.

Pemasaran dan jasa seringkali menjadi isu dalam pengembangan UMKM. Peningkatan pemasaran memiliki pengaruh signifikan terhadap peningkatan UMKM syariah. Hal ini menunjukkan bahwa pemasaran yang baik dan tepat sasaran akan mampu meningkatkan penjualan. Sebagaimana penelitian sebelumnya oleh Hanfan (2017), keunggulan produk ikotonik dapat meningkatkan kinerja pemasaran pada 
UMKM. Berdasarkan kerangka konseptual tersebut, maka rumusan persamaan regresi linear berganda dalam penelitian ini adalah:

$$
Y_{i t}=\alpha+\beta_{1} X_{1 i t}+\beta_{2} X_{2 i t}+\beta_{3} X_{3 i t}+\varepsilon
$$

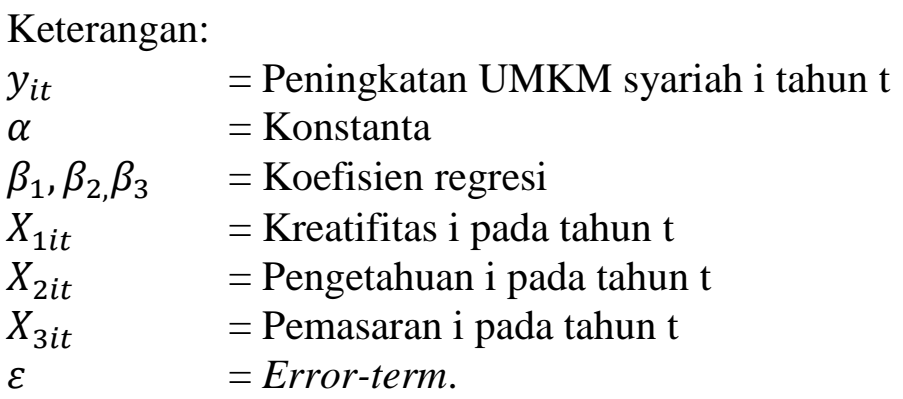

\section{METODE PENELITIAN}

Penelitian ini dilakukan dengan menggunakan metode diskriptif untuk menggambarkan kondisi riil yang sebenarnya dan hanya dapat dijelaskan dengan kata-kata dan tidak dapat dimanipulasi secara matematik, serta lebih menjelaskan kualitas daripada kuantitas (Walliman, 2011:71). Jenis penelitian ini adalah eksplanatori, yaitu penelitian menjelaskan bagaimana dan mengapa variabel X mempengaruhi variabel Y (Yin, 2018: 80). Metode pengambilan sampel dilakukan dengan cara non-probabilitas karena ukuran populasi yang tidak dapat dihitung dan dapat digunakan untuk studi tertentu agar cepat melakukan survei, karena sulit untuk mendapatkan akses ke seluruh populasi tetapi memberikan dasar yang lemah untuk generalisasi (Walliman, 2011:96).

Penelitian ini dilakukan dengan menggunakan sampel pelaku usaha di Kecamatan Kuta Alam Kota Banda Aceh. Jumlah sampel yang diteliti sebanyak 37 responden. Penelitian ini telah dilakukan pada tahun 2017. Sumber data yang digunakan pada penelitian ini adalah data primer. Data primer diperoleh dari penyebaran kuesioner kepada responden. Variabel yang digunakan dalam penelitian ini adalah tiga variabel independen, yakni kreatifitas, pengetahuan, dan pemasaran, serta satu variabel dependen yaitu peningkatan UMKM syariah. Pengujian terhadap instrumen penelitian berupa kuesioner menggunakan uji validitas yang digunakan dengan tujuan untuk mengukur ketepatan terhadap apa yang hendak diukur dalam penelitian, sehingga instrumen tersebut dapat dikatakan valid. Pengujian reliabilitas digunakan untuk melihat sejauh mana suatu pengukuran dapat dipercaya (Yusup, 2018).

Metode analisis yang digunakan adalah regresi linear berganda, yaitu penggunaan dua atau lebih dari dua variabel independen, tujuannya adalah untuk memprediksi variabel dependen berdasarkan kovariannya dengan seluruh variabel independen (Kothari, 2004:318) yang dilakukan secara parsial dan simultan menggunakan Statistical Package for Social Science (SPSS versi 16.0). Penelitian ini menggunakan pendekatan pengujian hipotesis. Menguji hipotesis berarti memberitahu (berdasarkan data yang telah dikumpulkan peneliti) apakah hipotesis tersebut diterima atau ditolak (Kothari, 2004:191). Pengujian hipotesis secara parsial dilakukan dengan menggunakan uji t, sedangkan pengujian secara simultan dilakukan dengan menggunakan uji F. Berbagai tes yang dapat digunakan saat menguji hipotesis, seperti uji-t, uji-F telah dikembangkan oleh para ahli statistik untuk pengujian ini. Pengujian hipotesis akan menghasilkan kesimpulan untuk menerima hipotesis atau menolaknya (Kothari, 2004:19). Untuk menguji 
ketepatan penggunaan model, peneliti menggunakan koefisien determinasi $\left(\mathrm{R}^{2}\right)$, yaitu suatu ukuran yang menunjukkan besarnya porsi sumbangan variabel penjelas terhadap variabel respon. Koefisien ini menunjukkan ragam (variasi) naik turunnya variabel dependen yang dapat dijelaskan oleh beragamnya nilai variabel independen (Siagian \& Sugiarto, 2006:259).

\section{HASIL PENELITIAN DAN PEMBAHASAN}

\section{Pengujian Validitas dan Reliabilitas Instumen Penelitian}

Penelitian ini menggunakan kuesioner untuk mengumpulkan data. Pengukuran dilakukan dengan menggunakan skala Likert dari 1 sampai dengan 5. Pengujian instrumen penelitian dilakukan dengan menggunakan analisis butir pernyataan. Setiap butir tertentu dievaluasi berdasarkan seberapa baik butir tersebut atau kemampuannya membedakan antara responden dengan skor tinggi dan rendah (Kothari, 2004:84). Selanjutnya, peneliti memberikan interpretasi terhadap koefisien korelasi product moment (r), sehingga uji signifikansi perlu dilakukan, yaitu membandingkan antara hasil $r_{\text {hitung dan }} r_{\text {tabel }}$. Apabila $r_{\text {hitung }}$ lebih besar daripada $r_{\text {tabel }}$, maka koefisien korelasi dinyatakan signifikan, sedangkan $\mathrm{r}_{\text {tabel }}$ diperoleh melalui tabel Pearson product moment berdasarkan jumlah data yang dianalisis (n) (Widiyanto, 2013:186). Metode pengujian instrumen penelitian untuk menentukan validitas dan reliabilitas dalam penelitian ini adalah metode product moment (Singh, 2006:224). Berdasarkan tabel Pearson product moment, $\mathrm{r}_{\text {tabel }}$ dalam penelitian ini adalah 0,324 .

Berdasarkan hasil pengujian yang telah dilakukan, nilai total korelasi pernyataan Butir 1: 0,725>0,324; Butir 2: 0,583>0,324; Butir 3: 0,554>0,324; Butir 4: 0,373> 0,324; dan Butir 5: 0,629>0,324. Hal ini menunjukkan bahwa semua butir pernyataan yang diajukan bernilai valid karena $r_{\text {hitung }}$ lebih besar daripada $r_{\text {tabel }}$. Pengujian reliabilitas dalam penelitian ini menggunakan nilai Cronbach Alpha. Pengujian variabel kreatifitas memiliki nilai Cronbach Alpha sebesar 0,811>0,324, variabel pengetahuan $0,932>0,324$, sedangkan variabel pemasaran 0,816>0,324. Hal ini menunjukkan bahwa semua butir pernyataan dinyatakan reliabel dan dapat dijadikan alat ukur yang tepat.

Tabel 4 Uji F

ANOVA $^{\mathrm{b}}$

\begin{tabular}{ccccccc}
\hline \multirow{3}{*}{1} & Model & Sum of Squares & df & Mean Square & F & Sig. \\
\cline { 2 - 7 } & Regression & 538.686 & 3 & 179.562 & 14.418 & $.000^{\mathrm{a}}$ \\
\cline { 2 - 7 } & Residual & 410.990 & 33 & 12.454 & & \\
\cline { 2 - 7 } & Total & 949.676 & 36 & & & \\
\hline
\end{tabular}

${ }^{\mathrm{a}}$ Predictors: (Constant), Kreatifitas, Pengetahuan, Pemasaran.

${ }^{\mathrm{b}}$ Dependent Variable: Peningkatan UMKM Syariah.

\section{Pengujian Pengaruh Simultan}

Pengujian secara simultan dilakukan untuk mengetahui apakah variabel independen (kreatifitas, pengetahuan, dan pemasaran) secara simultan berpengaruh terhadap variabel independen (peningkatan UMKM syariah). Berdasarkan hasil pengujian pengaruh simultan (Tabel 4), nilai signifikansi uji $F$ sebesar $0,000<0,05$ dan nilai $F_{\text {hitung }}$ $14,418>\mathrm{F}_{\text {tabel }} 2,88$. Hasil ini menunjukkan bahwa hipotesis pertama $\left(\mathrm{H}_{1}\right)$ dapat diteri- 
ma, yaitu terdapat pengaruh variabel kreatifitas (X1), pengetahuan (X2), dan pemasaran (X3) secara simultan terhadap peningkatan UMKM syariah (Y). Dengan hasil ini, maka secara simultan kreatifitas, pengetahuan, dan pemasaran berpengaruh secara signifikan terhadap peningkatan UMKM syariah di Aceh.

Kreatifitas, pengetahuan, dan pemasaran merupakan komponen yang saling melengkapi untuk mempengaruhi peningkatan UMKM syariah di Aceh. UMKM yang tidak mampu melakukan pemasaran dengan baik, tidak akan secara maksimal mampu meningkatkan laba usaha. Demikian pula halnya dengan kreatifitas, produk yang diciptakan tanpa kreatifitas tidak akan memiliki nilai jual, sehingga komponen UMKM syariah yang baik akan menghasilkan produk syariah yang mampu menarik minat wisatawan dan investor asing. Dalam perkembangan ekonomi syariah, upaya meningkatkan jumlah wisatawan tidak hanya dengan cara menjual budaya dan monumen bersejarah, tetapi penawaran produk syariah juga berpotensi meningkatkan pendapatan masyarakat setempat.

\section{Pengujian Pengaruh Parsial}

Pengujian pengaruh secara parsial dilakukan menggunakan uji t. Pengujian ini dilakukan untuk melihat pengaruh variabel independen (kreatifitas, pengetahuan, dan pemasaran) secara parsial terhadap variabel dependen (peningkatan UMKM syariah) sebagaimana ditunjukkan pada Tabel 5 berikut.

\begin{tabular}{|c|c|c|c|c|c|c|}
\hline & \multicolumn{6}{|c|}{$\begin{array}{c}\text { Tabel } 5 \text { Uji t } \\
\text { Coefficients }^{\mathrm{a}}\end{array}$} \\
\hline & \multirow[t]{2}{*}{ Model } & \multicolumn{2}{|c|}{ Unstandardized Coefficients } & \multirow{2}{*}{$\begin{array}{c}\begin{array}{c}\text { Standardized } \\
\text { Coefficients }\end{array} \\
\text { Beta }\end{array}$} & \multirow[t]{2}{*}{$\mathbf{t}$} & \multirow[t]{2}{*}{ Sig. } \\
\hline & & B & Std. Error & & & \\
\hline \multirow[t]{4}{*}{1} & (Constant) & 4.711 & 3.619 & & 1.302 & .202 \\
\hline & Kreatifitas & -.045 & .121 & -.043 & -.368 & .715 \\
\hline & Pengetahuan & .021 & .134 & .018 & .159 & .875 \\
\hline & Pemasaran & .767 & .119 & .757 & 6.442 & .000 \\
\hline
\end{tabular}

${ }^{\mathrm{a}}$ Dependent Variable: Peningkatan UMKM syariah.

Berdasarkan Tabel 5, model persamaan regresi linier berganda pada penelitian ini dapat dirumuskan sebagai berikut:

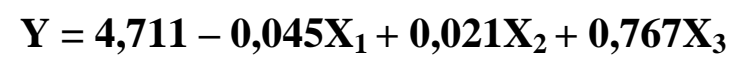

Pengujian hipotesis kedua $\left(\mathrm{H}_{2}\right)$, yaitu pengaruh variavel kreatifitas terhadap UMKM syariah memiliki nilai signifikansi sebesar 0,715 yang lebih besar dari 0,05 $(0,715>0,05)$ atau nilai $t_{\text {hitung }}(-0,368)<t_{\text {tabel }}(2,034)$, sehingga $\mathrm{H}_{2}$ ditolak. Artinya, variabel kreatifitas tidak berpengaruh secara signifikan terhadap peningkatan UMKM syariah. Hasil penelitian ini tidak sama dengan penelitian yang dilakukan oleh Hadiyati (2011) yang menunjukkan bahwa kreatifitas berpengaruh signifikan terhadap kewirausahaan. Hal ini dikarenakan kreatifitas tidak dapat secara parsial dan langsung meningkatkan UMKM syariah. Banyak faktor pendukung lain yang dianggap mempengaruhi peningkatan UMKM syariah, seperti pemasaran, pemberdayaan UMKM, dan pembiayaan perbankan syariah. Kreatifitas belum mampu meningkatkan UMKM syariah tanpa 
adanya dukungan dari pemerintah. Harapan yang terlalu tinggi dalam kerjasama bisa membatasi kreatifitas mitra usaha (Terziovski, 2003).

Pengujian hipotesis ketiga $\left(\mathrm{H}_{3}\right)$, yaitu pengaruh variabel pengetahuan terhadap peningkatan UMKM syariah. Penelitian ini menemukan bahwa nilai signifikansi variabel pengetahuan terhadap peningkatan UMKM syariah sebesar 0,875, lebih besar daripada $0,05(0,875>0,05)$ dan nilai $t_{\text {hitung }} 0,159<t_{\text {tabel }} 2,034$, sehingga $\mathrm{H}_{3}$ ditolak. Hasil ini menunjukkan tidak terdapat pengaruh yang signifikan variabel pengetahuan terhadap peningkatan UMKM syariah. Tidak selamanya pengetahuan berpengaruh terhadap peningkatan UMKM syariah. Hal ini membuktikan bahwa pengetahuan secara parsial tidak mampu menjadi unsur tunggal dalam peningkatan UMKM syariah. Gurteen (1998) dalam penelitiannya menyatakan bahwa ada sejumlah faktor yang sering dilupakan, seperti pengetahuan eksplisit, pengetahuan diam-diam, informasi, pengalaman, maupun ketrampilan yang tidak cukup untuk membuat pengetahuan produktif. Seseorang perlu memasukkan pengetahuan dalam tindakan agar bisa menjadi kompetensi. Dalley dan Hamilton (2015) melakukan penelitian tentang bisnis kecil dengan melihat pengetahuan, konteks, dan pembelajaran. Hasil penelitian mereka menunjukkan bahwa konflik budaya, model komunikasi, dan gaya pembelajaran yang dilakukan belum efektif untuk meningkatkan kinerja bisnis kecil. Hal tersebut membuktikan pula bahwa pengetahuan yang dimiliki harus pula disesuaikan dengan usaha yang dilakukan, sehingga tujuan perusahaan dapat tercapai. Untuk meningkatkan UMKM syariah diperlukan pengetahuan mendasar tentang syariat Islam.

Pengujian hipotesis keempat $\left(\mathrm{H}_{4}\right)$, yaitu pengaruh variabel pemasaran terhadap peningkatan UMKM syariah. Nilai signifikansi untuk variabel pemasaran sebesar 0,000 yaitu lebih kecil dari $0,05(0,00<0,05)$ dan nilai $t_{\text {hitung }} 6,442>t_{\text {tabel }} 2,034$, sehingga $\mathrm{H}_{4}$ diterima. Hasil tersebut dapat diartikan adanya pengaruh signifikan variabel pemasaran terhadap peningkatan UMKM syariah. Hasil penelitian yang dilakukan oleh Becherer dan Maurer (1997) menyatakan bahwa orientasi pemasaran memiliki hubungan dengan orientasi kewirausahaan dengan koefisien korelasi mencapai 0,69 ( $p<0,01)$. Hal ini membuktikan bahwa pemasaran merupakan instrumen penting yang harus dilakukan untuk meningkatkan UMKM syariah. Pelaku UMKM syariah dapat melakukan banyak hal untuk meningkatkan penjualan, seperti penggunakan teknologi digital. Penelitian oleh Eid dan El-Gohary (2013) menemukan bahwa pemasaran electronic marketing (EM) merupakan ukuran penggunaan teknologi perusahaan dengan dua variabel, yaitu EM anggaran dan EM alat. EM alat digunakan sebagian besar oleh perusahaan untuk pemasaran internet dan e-mail yang diikuti pemakaian seluler dan ekstranet. Keduanya berpengaruh signifikan dan dapat membantu peningkatan pemasaran pada perusahaan.

\section{Pengujian Koefisien Determinasi}

Nilai koefisien determinasi $\left(\mathrm{R}^{2}\right)$ mencerminkan seberapa besar variasi variabel peningkatan UMKM syariah dapat diterangkan oleh semua variabel independen, yaitu kreatifitas, pengetahuan, dan pemasaran. Berdasarkan Tabel 6 , hasil pengujian koefisien determinasi menunjukkan $\mathrm{R}^{2}$ sebesar 0,567 . Hasil ini bermakna bahwa variasi peningkatan UMKM syariah mampu dijelaskan oleh seluruh variabel independen (kreatifitas, pengetahuan, dan pemasaran) sebesar 56,7\% dan sisanya sebesar 43,3\% dijelaskan oleh variabel lain yang tidak digunakan di dalam model penelitian. 
Tabel 6. Uji Koefisien Determinasi

\begin{tabular}{ccccc} 
Model & $\mathbf{R}$ & R Square & $\begin{array}{c}\text { Adjusted } R \\
\text { Square }\end{array}$ & Std. Error of the Estimate \\
\hline 1 & $.753^{\mathrm{a}}$ & .567 & .528 & 3.529 \\
\hline
\end{tabular}

aredictors: (Constant), Kreatifitas, Pengetahuan, Pemasaran.

\section{Pengaruh Kreatifitas terhadap Peningkatan UMKM Syariah}

Hasil penelitian secara simultan menunjukkan bahwa kreatifitas berpengaruh terhadap peningkatan UMKM syariah, jika pengujian dilakukan secara parsial kreatifitas tidak berpengaruh signifikan terhadap peningkatan UMKM syariah. Hal ini menunjukkan bahwa upaya meningkatkan UMKM syariah dibutuhkan banyak faktor yang mendukung. Tanpa pemasaran yang baik, maka kreatifitas tidak memiliki nilai jual tinggi, sehingga tujuan peningkatan UMKM syariah pun tidak tercapai. Kreatifitas tidak cukup hanya dengan memunculkan ide. Oleh karena itu, motivasi kepada karyawan untuk berinovasi dan berkreasi sangat diperlukan (Rowe \& Nejad, 2009 dalam Ilyas, Munir, \& Sobarsyah, 2017).

Masih banyak UMKM yang belum mampu megembangkan ide dalam menjalankan usaha, sehingga kondisi itu menimbulkan kejenuhan dalam melakukan usaha dan sulit untuk bersaing. UMKM yang kreatif juga dituntut untuk mampu menggunakan teknologi terbaru dalam berproduksi, sehingga kreatifitas yang mereka miliki dapat meningkatkan perkembangan UMKM secara syariah dan bisa diterima secara internasional. Kreatifitas yang sebatas berupa ide sulit untuk dikembangkan lebih lanjut, karena tidak semua orang paham akan ide yang dimiliki orang lain. Pengembangan kreatifitas memerlukan inovasi yang mampu berkolaborasi dalam menciptakan kebaruan. Inovasi yang dikembangkan UMKM juga harus melihat arah pengembangan usaha terkini, seperti usaha berbasis syariah. Inovasi baru diperlukan untuk menciptakan produk-produk baru yang sesuai syariah. Selanjutnya, produk sesuai syariah akan mampu menjadikan icon dalam peningkatan UMKM tersebut, sehingga menjadi UMKM syariah yang dapat berkembang.

\section{Pengaruh Pengatahuan terhadap Peningkatan UMKM Syariah}

Pengetahuan tidak selamanya selalu mempengaruhi peningkatan UMKM syariah. Banyak faktor pendukung lain yang harus diperhitungkan, seperti modal, lingkungan, dan kondisi sosial politik. Dimensi budaya yang mempengaruhi keputusan masyarakat mengunjungi destinasi wisata Syariah didasarkan pada hal-hal seperti pengetahuan masyarakat tentang wisata syariah, kebiasaan masyarakat mengunjungi tempat-tempat wisata, faktor lingkungan sekitar, tingkat penghasilan, dan tingkat pendidikan masyarakat (Mardiah \& Herlinda, 2017). Namun, knowledge sharing kepada UMKM terjadi tidak hanya dari pemerintah, akademisi, atau pelaku bisnis besar saja. Knowledge sharing juga terjadi antarUMKM dan menjadi kunci utama keberhasilan UMKM dalam berkembang di era perdagangan global (Aribawa, 2016). Pengetahuan yang harus dimiliki oleh pelaku usaha UMKM haruslah sesuai dengan usaha yang dilakukan, sehingga hal itu dapat berdampak langsung terhadap peningkatan usahanya. Sayangnya, pengetahuan yang diperoleh oleh pelaku UMKM merupakan pengetahuan dan pelatihan umum yang bukan bidangnya.

Pelaku UMKM masih kurang mengupgrade pengetahuan-pengetahuan baru tentang bisnis dan produk syariah yang sedang menjadi trend, sehingga hal tersebut 
seharusnya dapat memberikan dampak positif terhadap usaha yang dilakukan apabila mereka mempelajarinya, seperti melakukan sertifikasi halal untuk produk yang dihasilkan. Keterbatasan waktu sering menimbulkan kesulitan untuk belajar dan mengikuti berbagai pelatihan yang diberikan, baik dari pemerintah maupun pihak swasta lainnya. Pelaku UMKM harus paham dengan usaha yang dijalankannya tersebut. Artinya, mereka mengetahui kelemahan dan kelebihan dalam usaha yang dijalankannya. Pelaku UMKM juga perlu melakukan evaluasi untuk mengendalikan kemajuan usahanya. Hal ini bisa dilakukan dengan menganalisis perkembangan usaha, baik dari segi manajemen, pemasaran, maupun keuangan. Selanjutnya, pelaku UMKM dapat pula meningkatkan kemauan untuk mengupgrade perkembangan usaha yang diperlukan dari UMKM biasa menuju UMKM syariah.

\section{Pengaruh Pemasaran terhadap Peningkatan UMKM Syariah}

Kinerja pemasaran merupakan salah satu sumber daya organisasi. Kapabilitas organisasi dapat mengatur sumber daya yang dimiliki berupa modal organisasi, sehingga semakin tinggi keunggulan bersaing, maka semakin tinggi kinerja pemasaran (Hanfan, 2017). Pemasaran yang baik dapat meningkatkan kunjungan wisata. Hal ini sejalan dengan penelitian yang dilakukan oleh Ramadhany \& Ridlwan (2018) yang menyatakan bahwa meningkatnya kunjungan wisatawan menjadi tolak ukur meningkatnya pendapatan masyarakat. Banyaknya wisatawan yang berkunjung, maka pendapatan masyarakat pun akan meningkat, sehingga peran UMKM syariah dalam peningkatan wisatawan syariah menjadi semakin penting. Sebagaimana obyek wisata kota Sabang, kurangnya UMKM menjadikan sedikitnya produk yang dihasilkan, sehingga harga souvenir dan barang-barang lainnya relatif mahal. Begitu pula dengan wisatawan mancanegara, sangat sedikit uang yang mereka belanjakan, karena minimnya produk yang dipasarkan, serta produk unggulan daerah yang dihasilkan, sehingga berdampak pada menurunnya jumlah kunjungan wisatawan. Namun, banyak faktor lain pula yang berpengaruh terhadap destinasi wisata syariah sebagaimana hasil penelitian yang dilakukan Mardiah \& Herlinda (2017) yang menyatakan bahwa faktor-faktor budaya, sosial, individual, dan psikologi berpengaruh positif terhadap keputusan mengunjungi destinasi wisata syariah.

Pelaku usaha memainkan peran sentral dalam pembentukan usaha baru. Aktivitas kewirausahaan adalah upaya menciptakan kegiatan ekonomi melalui eksplorasi peluang, produk baru, proses, dan pasar (Siaw \& Rani, 2012). Pemasaran merupakan instrumen penting dalam setiap usaha, tidak terkecuali UMKM. Sistem pemasaran yang terus berkembang mengharuskan pelaku UMKM mampu mengikuti dan mengembangkannya. Teknologi mengarahkan pelaku UMKM mampu bersaing menggunakan sosial media. Saat ini, banyak teknologi finansial yang bermunculan dan tidak membatasi pelaku usaha besar, usaha menengah, atau pun kecil untuk menggunakannya. Hal ini mengindikasikan bahwa terbuka pasar yang lebih luas bagi pelaku usaha untuk memasarkan produknya dengan bantuan teknologi, sehingga UMKM syariah dapat pula berkembang pesat dan menjangkau target market yang lebih luas.

\section{KESIMPULAN DAN SARAN}

Berdasarkah hasil analisis dan pengujian hipotesis, maka dapat disimpulkan bahwa kreatifitas, pengetahuan, dan pemasaran secara simultan berpengaruh terhadap peningkatan UMKM Syariah. Namun, secara parsial kreatifitas tidak memiliki pengaruh 
signifikan terhadap peningkatan UMKM Syariah, karena kreatifitas tanpa pemasaran yang baik tidak dapat mendatangkan wisatawan untuk mengunjungi kota wisata syariah. Pengetahuan juga tidak memberikan pengaruh signifikan terhadap peningkatan UMKM syariah. Temuan ini menunjukkan bahwa pengetahuan yang tidak diaplikasikan dalam penciptaan produk secara tepat tidak akan dapat mempengaruhi peningkatan UMKM syariah. Pelaku UMKM dituntut untuk mengetahui target pasar secara tepat agar mampu memasarkan produknya tepat sasaran.

Di sisi lain, pemasaran berpengaruh signifikan terhadap peningkatan UMKM Syariah. Pemasaran yang tepat dapat meningkatkan penjualan dan peluang bagi UMKM untuk berkembang. Pemasaran kota Banda Aceh dalam balutan syariah dapat meningkatkan kunjungan wisata syariah terutama dalam penjualan produk-produk syariah di Aceh. Secara tidak langsung, wisatawan akan mencari produk khas daerah, sehingga peningkatan wisata syariah akan memperbesar permintaan terhadap produk khas dan keberadaan UMKM syariah. Berdasarkan hasil penelitian ini, pelaku UMKM diharapkan mampu meningkatkan pemasaran kota wisata syariah melalui peningkatan produksi, serta pendampingan, penyuluhan, dan pelatihan kepada pelaku UMKM untuk mendukung peningkatan sumber daya manusia. Pada gilirannya, mereka akan memiliki kemampuan untuk membaca peluang pasar guna mendukung peningkatan wisatawan berbasis syariah.

\section{DAFTAR REFERENSI}

Agyapong, D. (2010). Micro, Small, and Medium Enterprises' Activities, Income Level, and Poverty Reduction in Ghana: A Synthesis of Related Literature. International Journal of Business and Management, 5(12), 196-205.

Aribawa, D. (2016). Pengaruh Literasi Keuangan terhadap Kinerja dan Keberlangsungan UMKM di Jawa Tengah. Jurnal Siasat Bisnis, 20(1), 1-13.

Arsyad, A. (2008). Media Pembelajaran. Jakarta: PT Raya Grafindo Persada.

Asih, S. M \& Asih S. K. (2015). Marketing Strategy Implementation in Developing Sharia Tourism in Indonesia. International Proceedings of Manajement and Economy IPEDR (Vol. 84). Singapore: LACSIT Press.

BAPPENAS. (2015). Masterplan Arsitektur Keuangan Syariah Indonesia. Jakarta: Badan Perencanaan Pembangunan Nasional.

Battour M. M., Ismail M. N. \& Battor M. (2010). Toward Halal Tourism Market. Tourism Analysis, 15, 1-10. https://doi.org/10.3727/108354210X12864727453 304.

Becherer, R. C., \& Maurer, J. G. (1997). The Moderating Effect of Environmental Variables on the Entrepreneurial and Marketing Orientation of Entrepreneur-led Firms. Entrepreneurship Theory and Practice, 22(1), 47-58. https://doi.org/ $10.1177 / 104225-879702200103$.

Bharati, P. \& Chaudhury, A. (2006). Current Status of Technology Adoption: Micro, Small, and Medium Manufacturing Firm in Boston. Communication of the ACM, 49(10), 88-93.

BPPN (2018). Masterplan Ekonomi Syariah Indonesia 2019-2024. Jakarta: Badan Perencanaan Pembangunan Nasional.

BPS (2018). www.bps.go.id. Diakses 10 Februari 2018. 
Dalley, J. \& Hamilton, B. (2015). Knowledge, Context, and Learning in the Small Business. International Small Business Journal, 18(3), 51-59. https://doi.org/ $10.1177 / 0266242600183003$.

Dinas Koperasi dan UMKM Provinsi Aceh (2018). Laporan Rekapitulasi Direktori Industri Kecil dan Menengah Provinsi Aceh. Aceh: Pemerintah Provinsi Aceh.

Ellitan, L. (2002). Praktik-praktik Pengelolaan Sumber Daya Manusia dan Keunggulan Kompetitif Berkelanjutan. Jurnal Manajemen dan Kewirausahaan, 2(2), 65-76.

Eid, R. \& El-Gohary, H. (2013). The impact of E-marketing use on small business enterprises' marketing success. The Service Industries Journal, 33(1), 31-50. https://doi.org/10.1080/02642069.2011.594878.

Gurteen, D. (1998). Knowledge, Creativity, and Innovation. Journal of Knowledge Management, 2(1), 5-13. https://doi.org/10.1108/13673279810800744.

Hadiyati, E. (2011). Kreatifitas dan Inovasi Berpengaruh terhadap Kewirausahaan Usaha Kecil. Jurnal Manajemen dan Kewirausahaan, 13(1), 8-16. https://doi.org/ 10.9744/jmk.13.1.8-16.

Hanfan, A. (2017). Membangun Keunggulan Produk IKOTONIK untuk Meningkatkan Kinerja Pemasaran UMKM. DeReMa Jurnal Manajemen, 12(2), 162-186.

Hejazziey, D. (2009). Pemberdayaan Koperasi, Usaha Mikro, Kecil, dan Menengah (UMKM) melalui Lembaga Keuangan Syariah (LKS) untuk Mengentaskan Kemiskinan dan Pengurangan Pengangguran. Al-Iqtishad, 1(1), 31-52.

Henderson, J. C. (2009). Islamic Tourism Reviewed. Tourism Recreation Research, $32(2), 207-211$.

Henderson, J. C. (2010). Sharia-Compliant Hotels. Tourism and Hospitality Research, $10,246-254$.

Hendrawan, A., Kuswantoro, F., \& Sucahyawati (2019). Dimensi Kreatifitas dan Pengembangan Usaha Mikro, Kecil, dan Menengah (UMKM). Jurnal HUMMANSI (Humaniora, Manajemen, Akuntansi), 2(1), 25-36.

Ilyas, G. B., Munir, A. R., \& Sobarsyah, M. (2017). Role of Strategic Leadership, Entrepreneurial Orientation, and Innovation on Small and Medium Enterprise Performance. International Journal of Economic Research, 14(15), 61-72.

Kamali, M. H. (2011). Tourism and The Halal Industry: A Global Shari'ah Perspective. Presented an Earlier Version of Article at The World Islamic Tourism Forum. 1213 July 2011. Organized by The Global Islamic Tourism Organisation (GITO) Malaysia and IAIS Malaysia.

Kementerian Pariwisata. (2015). http://www.kemenpar.go.id/asp/detil.asp?c=7\&id= 2900. Diakses tanggal 15 Juni 2017.

KNKS (2017). Masterplan Arsitektur Keuangan Syariah Indonesia. Komite Nasional Keuangan Syariah.

Kothari, C. R. (2004). Research Methodology: Methods \& Techniques. New Delhi: New Age International Limited Publishers.

Lembaga Pengembangan Perbankan Indonesia. www.lppi.or.id. Diakses Februari 2018.

Mardiah, A. \& Herlinda, H. (2017). Analisis Perilaku Masyarakat terhadap Keputusan Mengunjungi Destinasi Wisata Syariah di Sumatera Barat. Sosial Budaya, 14(2), 200-2007. 
Nasution, M. E., Setyanto, B., Huda, N., Mufraeni, M. A., \& Utama, B. S. (2012). Pengenalan Eksklusif Ekonomi Islam. Cetakan ke-4. Jakarta: Kencana.

Nitisusastro, M. (2010). Kewirausahaan \& Manajemen Usaha Kecil. Bandung: Alfabeta.

Permadi, L. A., Darwini S., Retnowati W., Negara I. K., \& Septiani E. (2018). Persepsi dan Sikap Masyarakat terhadap Rencana Dikembangkannya Wisata Syariah (Halal Tourism) di Provinsi Nusa Tenggara Barat. Jurnal Ekonomi dan Keuangan Syariah, 2(1), 34-53.

Ramadhany, F. \& Ridlwan, A. A. (2018). Implikasi Pariwisata Syariah terhadap Peningkatan Pendapatan dan Kesejahteraan Masyarakat. Muslim Heritage, 3(1), 147164.

Rehman, M., Mahmood, A. K. B., Sugathan, S. K. \& Amin, A. (2010). Implementation of Management in Small and Medium Enterprises. Journal of Knowledge Management Practice, 11(1).

Santoso \& Rahmawati, U. (2016). Produk Kegiatan Usaha Perbankan Syari'ah dalam Mengembangkan UMKM di Era Masyarakat Ekonomi ASEAN (MEA). Jurnal Penelitian, 10(2), 322-344.

Siaw, C. L. \& Rani, N. S. A. (2012). A Critical Review on The Regulatory and Legislation Challenges Faced by Halal Start-up SMEs Food Manufacturers in Malaysia. Procedia-Sosial and Behavioral Science, 57, 541-548. https://doi.org/ 10.1016/j.sbspro.2012.09.1222.

Singh Y. K. (2006). Fundamental of Reasearch Methodology and Statistics. New Age International (P) Limited Publishers: New Delhi.

Sholihin, A. I. (2010). Pedoman Umum Lembaga Keuangan Syariah. Jakarta: PT Gramedia Pustaka Utama.

Sekretariat Negara (2008). Undang-Undang Nomor 20 Tahun 2008 tentang Usaha Mikro, Kecil, dan Menengah (Lembaran Negara Republik Indonesia Tahun 2008 Nomor 93 Tambahan Lembaran Negara Republik Indonesia Nomor 3540).

Sekretaris Daerah Aceh (2016). Qanun Nomor 8 tahun 2016 tentang Sistem Jaminan Produk Halal.

Siagian, D. \& Sugiarto (2006). Metode Statistika: Untuk Bisnis dan Ekonomi. Jakarta: PT Gramedia Pustaka Utama.

Suci, Y. R. (2017). Perkembangan UMKM (Usaha Mikro, Kecil, dan Menengah) di Indonesia. Jurnal Ilmiah Cano Ekonomos, 6(1), 51-58.

Sukamto (2012). Memahami Mekanisme Pasar dalam Ekonomi Islam. Jurnal Sosial Humaniora, 5, 19-32.

Tambunan, T. (2012). UMKM di Indonesia. Bogor: Ghalia Indonesia.

Terziovski, M. (2003). The relationship between networking practices and business excellence: a study of small to medium enterprises (SMEs). Measuring Business Excellence, 7(2), 78-92. https://doi.org/10.1108/13683040310478011.

Walliman, N. (2011). Research Methods: The Basic. London: Routledge.

Wibisono, A. D. (2015). Pengaruh Pembiayaan Usaha Mikro, Kecil, dan Menengah (UMKM) dan Likuiditas terhadap Resiko Pembiayaan Perbankan Syariah di Indonesia Periode 2010-2014. Akrual, 6(2), 104-114. 
Widiyanto M. A. (2013). Statistik Terapan: Konsep \& Aplikasi SPSS/LISREL dalam Penelitian Pendidikan Psikologi \& Ilmu Sosial Lainnya. PT Elex Media Komputindo: Jakarta.

Yaacob, Y. \& Azmi I. A. G. (2012). Entrepreneurs' Social Responsibilities From Islamic Perspective: A Study of Muslim Entrepreneurs in Malaysia. ProcediaSosial and Behavioral Science, 58, 1131-1138.

Yin, R. K. (2018). Case Study Research and Application: Design and Methods. Los Angeles: Sage Publication.

Yusup, F. (2018). Uji Validitas dan Reliabilitas Instrumen Penelitian Kualitatif. Jurnal Tarbiyah: Jurnal Ilmiah Kependidikan, 7(1), 17-23. https://dx.doi.org/10.18592/ tarbiyah.v7i1.2100.

Zimmerer, T. W., Scarborough, N. M. \& Wilson, D. (2008). Kewirausahaan dan Manajemen Usaha Kecil. Jakarta: Salemba Empat. 